\title{
Students' Numeracy Skills Relating to Algebra Topic Using COVID-19 Context
}

\author{
Septi Puspita Sari ${ }^{1}$, Zulkardi'2, Darmawijoyo ${ }^{3}$ \\ 1,2,3 Department of Mathematics Education, Universitas Sriwijaya, Indonesia \\ 15septipuspita1609@gmail.com, ${ }^{2}$ zulkardi@unsri.ac.id,3darmawijoyo@unsri.ac.id
}

\begin{tabular}{l}
\hline \hline \\
\hline Article History: \\
Received : 15-01-2021 \\
Revised : 02-04-2021 \\
Accepted : 03-04-2021 \\
Online : 16-04-2021 \\
\hline
\end{tabular}

\section{Keywords:}

Minimum Competency Assessment;

Numeration;

Algebra;

COVID-19 Context;

\begin{abstract}
The Minimum Competency Assessment (MCA) is a basic competency assessment that will be carried out by the ministry of education and culture in Indonesia in 2021, one of the assessments is numeracy. Algebraic material is one of the important materials for students to learn related to everyday problems. The use of context is important in learning algebra. In this regard, the discussion which is now a topic of discussion for all groups not only from Indonesia but the world, namely Covid-19, can be an interesting context to raise. This study, describes the numeracy skills of students in working on algebraic questions, research subjects are students with heterogeneous abilities (medium, high, low) using a descriptive qualitative approach, with collection techniques in the form of tests, and interviews. The research subjects were grade VII students. Wherefrom the research, it was found that there were still unfulfilled numerical indicators, namely indicators of interpreting it to conclude. While indicators that often appear are using numbers and mathematical symbols in solving problems in life.
\end{abstract}

\section{A. INTRODUCTION}

Algebra is a topic that must be mastered by students because algebra knowledge and skills both implicitly and explicitly can be used in daily life activities directly or as a prerequisite for learning (Jupri et al., 2014) . In the 2013 curriculum, algebra is used as a prerequisite for various materials in mathematics (MOEC, 2016)

In fact, among Indonesian students, algebra is still a big problem, because students have difficulty learning algebra starting from mathematization (Math), applying algebraic operations, understanding algebraic expressions to being too algorithmic and some students tend to avoid it once they learn this algebra topic (Cai et al., 2005). Students tend to incomplete in recognizing well-known structures (the students will experience cognitive barriers if there is no similar example) in learning algebraic (Juniarti et al., 2017)

The negative nature of mathematics begins when students are in high school because it is influenced by several factors, one of which is the lack of interest in mathematics material so that it has an impact on the results of mathematics itself, (Mazana et al., 2019) One of them is 
in international events such as PISA. PISA in the last two decades has shown the instability of the achievements of Indonesian students at the international level (OECD, 2019).

Referring to the PISA results, recently, Mas Nadiem Makarim has launched the Freedom of Learning Program by carrying out two learning concepts, namely "independence" and "independence". In line with that, (Mustaghfiroh, 2020) explains that these concepts reflect the learning that must explore maximally the intelligence, abilities, and potential of students in a fun, democratic, flexible, natural, and flexible manner,(Dewey, 2020). Through this program, 4 breakthroughs have been launched, one of which is implementing the minimum competency assessment (MCA) starting in 2021 as a substitute for the National Examination which focuses on numeracy (Handayu, 2020), and (Tohir, 2019)

According to (Muta'ali, 2020) numeracy is the ability of students to analyze real situations and encourage students to master symbols, numbers, and also basic mathematics used in everyday life, not just reading and counting. According to (GLN, 2017), (Kus, 2018), and (Kusaeri, 2020), numeracy includes skills in applying mathematical rules and concepts in everyday life in real situations, where problems have many possible solutions and are unstructured. The ability contained in numeracy itself is the ability to solve problems, analyze, interpret, formulate, and convey ideas or views, in various forms and situations (Maulidina \& Hartatik, 2019)

The use of contextual questions plays an important role in learning Algebra (Hott \& Dibbs, 2020). where it can be seen as a brain activity that shows the development of algebra from the formal level to the abstract, (Wijaya, 2016). In the PISA context it is important to use especially those that raise issues that are trending as well as those that students have often or have encountered, to attract attention as well so that students understand the existing problems, (Maharani et al., 2019), (Yansen et al., 2019), (Rawani et al., 2019), and (Jannah et al., 2019)

On 11 March 2020, WHO stated COVID-19 as the pandemic disease, Since the pandemic took place, community activities in the world from all fields, social activities began to change until locks were applied everywhere, (Güngör et al., 2020). In the education sector, there is also the impact of this pandemic, where almost all countries undertake distance education or online, and this is a challenge for educators as well as for the students themselves (Koçoğlu \& Tekdal, 2020) and (Moralista \& Oducado, 2020). This is a trending issue around the world. Because it is often talked about and everyone knows about it. Therefore, Covid-19 can be used as a context in mathematics.

Previous research has existed regarding numeracy skills, namely (Maulidina, 2019) which discusses the numeracy abilities of high-ability elementary school students, also (Mahmud \& Pratiwi, 2019) which discusses students' numeracy abilities in unstructured problem-solving. Related to the context of Covid-19 exists (Nusantara et al., 2020a, 2020b). However, there has been no research related to numeracy skills with algebraic problems using the PISA framework using Covid-19. Therefore this study aims to describe students' numeracy skills in algebraic content using the Covid-19 context. 


\section{B. METHODS}

This research is a descriptive study with a qualitative approach, which aims to describe the numeracy skills of students working on algebraic questions, where the resulting data is indepth, more complete, and meaningful so that the research objectives are achieved. According to (Sugiyono, 2017) triangulation is a data collection technique by combining data from various data collection techniques, data collection techniques used in this research are tests and interviews. The data analysis techniques used consisted of reduction (taking only important parts), display and verification data, (Sugiyono, 2017). During pandemic, educational researchers should have a broad knowledge of issues such as distance education, organizational change, health protocols and other issues surrounding education as well as health before and at the time of the research, this is important to consider in the research that will be carried out (DeMatthews et al., 2020).

Therefore, this research was conducted online, which uses zoom meeting assistance in data collection. The research subjects were students of grade VII in Harapan Mulia Integrated Islamic Junior High School, as many as 4 people consisting of students with high, medium, and low abilities.

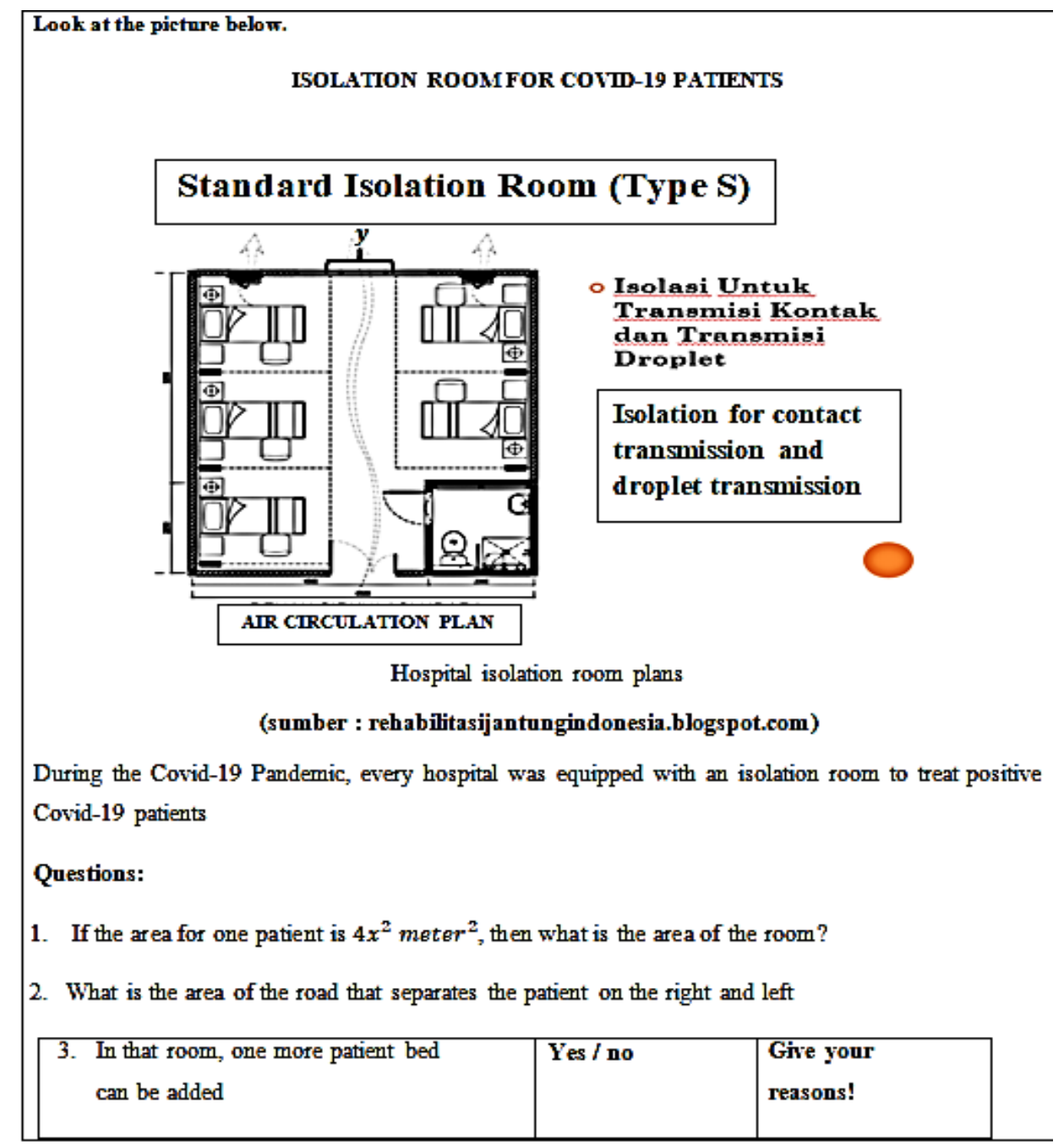

Figure 1. Numeration Test Questions 
Indicators used numeracy contained in GLN (2017)

Table 1. Indicators of Numeracy Skills

\begin{tabular}{cl}
\hline No & \multicolumn{1}{c}{ Indicator } \\
\hline 1 & $\begin{array}{l}\text { Can use various kinds of numbers or symbols related to basic mathematics in solving } \\
\text { everyday life problems. }\end{array}$ \\
\hline 2 & $\begin{array}{l}\text { Able to analyze information displayed in various forms (graphs, tables, charts, diagrams, and } \\
\text { so on). }\end{array}$ \\
\hline 3 & Interpret the results of the analysis to predict and make decisions. \\
\hline
\end{tabular}

\section{RESULT AND DISCUSSION}

From the questions that have been developed, you get questions that are ready to use after going through a series of development processes, after which you can see what numerical indicators are available from the questions, more clearly in the table below.

Table 2. Numeration Indicators in Question

\begin{tabular}{cccc}
\hline question & \multicolumn{3}{c}{ Indicator } \\
\cline { 2 - 4 } number & 1 & 2 & 3 \\
\hline 1 & $\checkmark$ & $\checkmark$ & $\checkmark$ \\
\hline 2 & $\checkmark$ & $\checkmark$ & $\checkmark$ \\
\hline 3 & - & $\checkmark$ & $\checkmark$ \\
\hline
\end{tabular}

\section{Information:}

Indicator 1 : Can use various kinds of numbers or symbols related to basic mathematics in solving everyday life problems.

Indicator 2 : Able to analyze information displayed in various forms (graphs, tables, charts, diagrams, and so on).

Indicator 3 : Interpret the results of the analysis to predict and make decisions.

\section{Descriptions of student answers}

a. Student 1 (S1-High Ability)

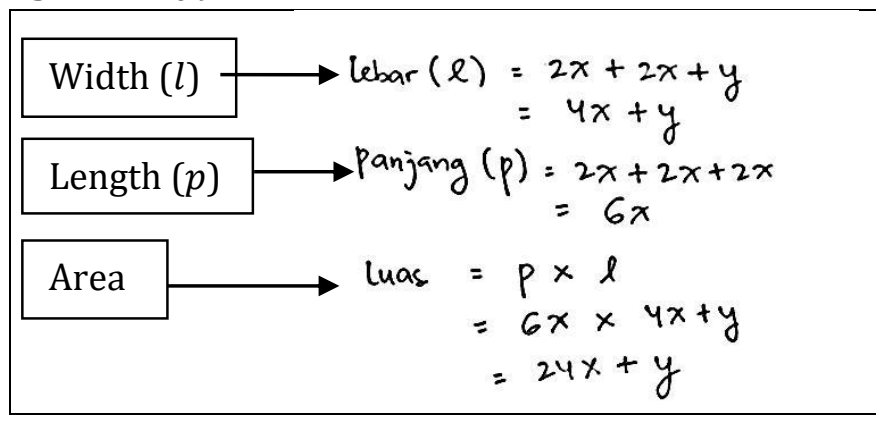

Figure 2. Answer Number 1 from Student 1(S1)

From the answers, students answer after reading the information that is picture information. But in questions that attract students, there are still difficulties, students are still wrong in calculations so that the answers written are wrong. S1 can analyze well when the following interviews were conducted with S1: 
Table 3. Interview with S1 for Answer Number 1

\begin{tabular}{|c|c|}
\hline $\mathrm{P}$ & In this matter what is known? \\
\hline S1 & The area of a patient is $4 \mathrm{x}$ the power of 2 meters to the power of 2 \\
\hline$P$ & What's the problem? \\
\hline S1 & The problem is the size of the room is not known \\
\hline $\mathrm{P}$ & Who was asked what? \\
\hline S1 & Area for one patient area \\
\hline$P$ & Means S1, how about the answer? \\
\hline S1 & $\begin{array}{l}\text { The area of a patient's area is } 4 \mathrm{x} \text { the power of } 2 \text { meters to the power of } 2 \text {, so } \\
\text { we have to find it, that's what the area of the room is looking for, so we have to } \\
\text { find the length times the width, right? The length is } 2 x+2 x+y \text { while the } \\
\text { width is } 4 x+y \text { so the length is the same as } 2 x+2 x+2 x=6 x \text { the area is } \\
24 x+y\end{array}$ \\
\hline
\end{tabular}

For number 1 which only appears are indicators 1 and 2 .

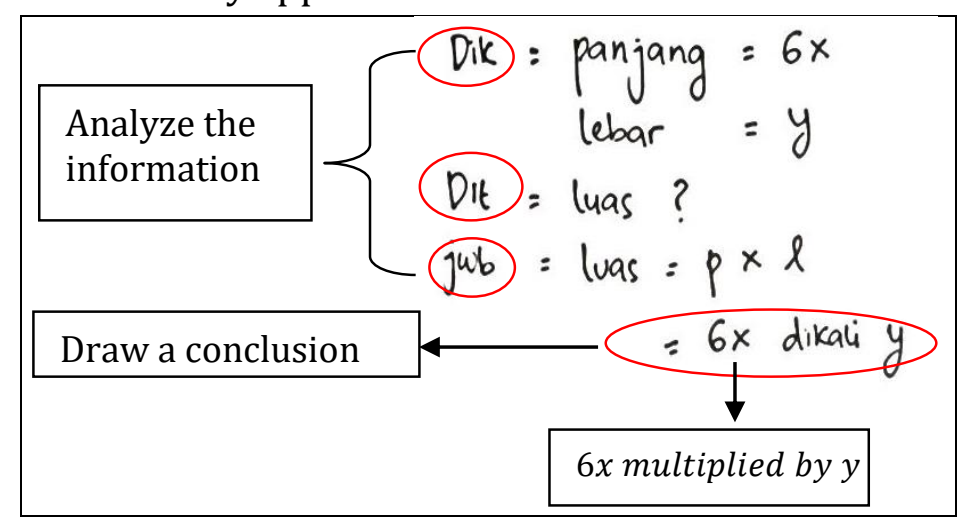

Figure 3. S1 Answer Question Number 2,

From the answer, it can be seen that the indicator using numbers and basic mathematical symbols in solving problems of daily life has not fulfilled it, because S1 does not use the operation symbol times but writes it with the word "multiplied", this is confirmed by the following interview.

Table 4. Interview with S1 for Answer Number 2

\begin{tabular}{ll}
\hline P & Here S1 write "multiplied", why don't you just make the operation symbol? \\
\hline S1 & $\begin{array}{l}\text { Afraid to be confused, the problem is } 6 x, x \text { with the multiplication symbol is } \\
\text { similar so it's like confused, so I'm not confused, I made the number "multiplied" }\end{array}$ \\
\hline
\end{tabular}

For indicators of analyzing and interpreting the results of the analysis, it appears from students' answers as well as the results of interviews, where for S1 answer number 2 answers correctly.

\begin{tabular}{|l|l|}
\hline $\begin{array}{l}\text { Tidak, karena jika ditambah luas daerah pasien } \\
\text { akan jadi sempit }\end{array}$ & $\begin{array}{l}\text { No, because if you add it, the patient } \\
\text { area will be narrow }\end{array}$ \\
\hline
\end{tabular}

Figure 4. S1 Answer Number 3 
For the S1 answer to question number 3, the two indicators contained in question number 3 appear both from the answers and interviews.

b. Student 2 (S2-Medium Ability)

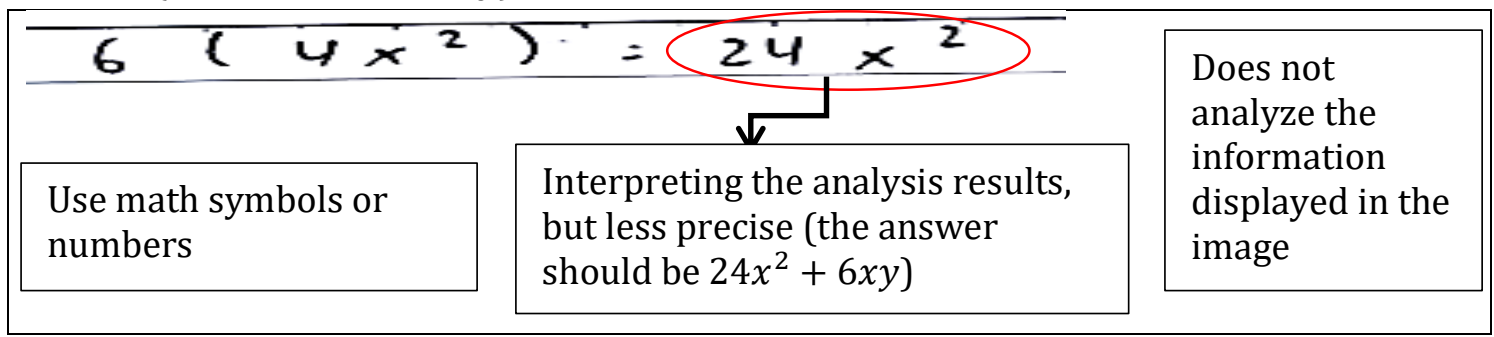

Figure 5. Answer Number 1, S2

Based on the results, it can be seen that S2 did not write down the answer completely, there is nothing known, what was asked and the answer was short, such as there was no process in answering the question, the indicators that emerged from the answer were indicators using mathematical symbols and numbers.

S2 is not accurate with the information in which the image has been given information regarding the width of the road, but S2 only calculates the space to find the area of the room. At the time of the interview to answer question number 1, S2 did not use all the information in the picture to answer questions. So, only one indicator emerged, namely using numbers and symbols in solving problems.

Table 5. Interview with S2 for Answer Number 1

\begin{tabular}{ll}
\hline P & What is known from the problem? \\
\hline S2 & $\begin{array}{l}\text { The problem is that how large the room is, in that room there are } 5 \\
\text { bedrooms and } 1 \text { bathroom but the bathrooms are also counted, each room }\end{array}$ \\
& has an area of $4 x^{2}$ meter $^{2}$ so that is multiplied by 6 to be $24 x^{2}$ \\
\hline P & Is that all? \\
\hline S2 & For this one, yes
\end{tabular}

Just like the previous answer, S2 did not write down the answer completely, nothing is known, what was asked and the answer was short, but the answer to question number 2 is correct, the indicator that appears from the answer is an indicator using mathematical symbols and numbers in solving problems are also indicators of interpreting the results of the analysis.

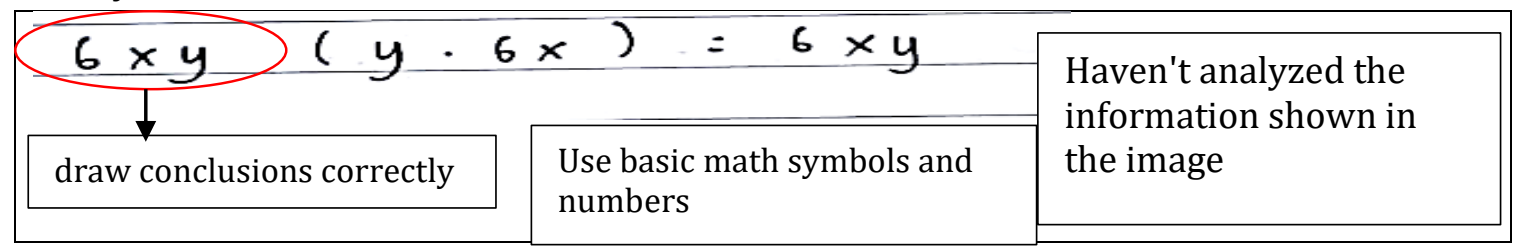

Figure 6. Answer Number 2, S2

In the student's answer, there is no visible indicator of analyzing information but when interviewing students can explain well the questions related to indicators of analyzing information. 
Table 6. Interview with S2 for Answer Number 2

\begin{tabular}{ll}
\hline $\mathrm{P}$ & What about this question? \\
\hline S2 & The area of the road \\
\hline $\mathrm{P}$ & What is known from the questions \\
\hline S2 & Same as before, and the width of the road is y \\
\hline
\end{tabular}

Therefore, the three indicators of numeracy ability are for question number 2 . For question number 3 , because there are only two indicators in the question, the indicator that appears from the S2 answer is to analyze the answers and results of the interview, because in interpreting the results of the interview I do not write down the reasons for the questions, while in the questions students are asked to write down the reasons.

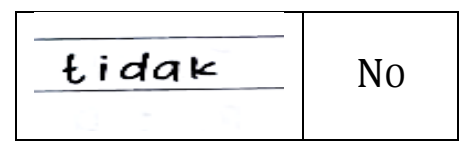

Figure 7. Answer Number 3 from S2

When being interviewed, students can explain the results of the analysis for answer number 3. Therefore, both indicators are met.

Table 7. Interview with S2 for Answer Number 2

\begin{tabular}{ll}
\hline $\mathrm{P}$ & What is the answer to this question S2? \\
\hline S2 & No \\
\hline P & Why? \\
\hline S2 & $\begin{array}{l}\text { Actually if you want to build the room you can walk, but later in the next } \\
\text { room you can't get out, so according to me you can't }\end{array}$ \\
\hline
\end{tabular}

\section{c. Student 3 (S3-Low Ability)}

For questions 1 and 2, S3 does not understand the information in question S3 only knows what the problem is. From the S3 answers to questions, 1 and 2 S3 also make many errors in calculations in algebraic operations.

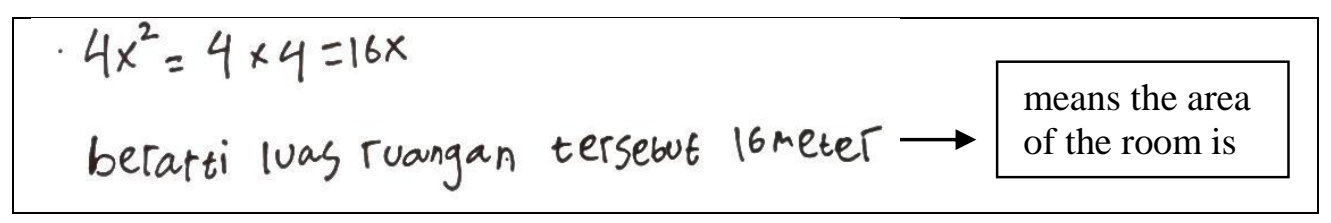

Figure 8. Answer Number 1 from S3

It can be seen that $\mathrm{G} 4 x^{2}$ as $4 \times 4$ and the result is $16 x$, while for the conclusion $\mathrm{G}$ writes 16 meters as the answer which is clearly wrong.

Table 8. Interview with S3 for Answer Number 1

\begin{tabular}{ll}
\hline P & What do you know from the questions?? \\
\hline S3 & (pointing to the question) $4 x^{2}$ is miss, room \\
\hline P & What was asked? \\
\hline S3 & The size of this large room \\
\hline
\end{tabular}




\section{5 meter}

Figure 9. Answer Number 2 from S3

S3 answers are incomplete, they only answer 5 meters, from S3's answer there is no numeration indicator visible when students answer question number 2

Table 9. Interview with S3 for Answer Number 2

\begin{tabular}{ll}
\hline P & What do you know from the questions? \\
\hline S3 & Same as before miss \\
\hline P & What's the problem? \\
\hline S3 & Road area \\
\hline P & S3 answer 5 meters, what's this? Why? \\
\hline S3 & That's because for example the room is 100 meters deep, so if $16+16$ is \\
& like 5 meters miss \\
\hline P & So S3 is using estimates for this problem? \\
\hline S3 & Yes miss because i don't understand \\
\hline
\end{tabular}

From the interview conversation, S3 admitted that S3 had difficulty understanding the problem and answered predictably. So, the three numeration indicators do not appear in S3's answer to question number 2.

for question number 3, S3 answered correctly as well as the reasons where the three indicators were met.

\begin{tabular}{|l|l|}
\hline $\begin{array}{l}\text { Eidak, karena menurut dena fuangan velah Furriour Lain jadi ngga bisa } \\
\text { ditanbah Kasur }\end{array}$ & $\begin{array}{l}\text { No, because according to the room plan there } \\
\text { are already other furniture, so you can't add } \\
\text { more mattresses. }\end{array}$ \\
\hline
\end{tabular}

Figure 10. Answer Number 3 from S3

Also reinforced by the following interview:

Table 10. Interview with S3 for Answer Number 3

\begin{tabular}{ll}
\hline P & Okay how about this one? \\
\hline S3 & The answer to G for this question is not miss, the reason is because it \\
& doesn't fit anymore, according to the plan, it's narrow \\
\hline
\end{tabular}

\section{Disscusion}

Students' numeracy skills for indicators can use various kinds of numbers or symbols related to basic mathematics in solving daily life problems. There are still some students who have difficulty using numbers and mathematical symbols in solving problems, such as students who have difficulty writing symbols multiplication operations in algebra, especially after the variable, even though the actual meaning is correct. And some students do not understand the meaning of the symbols they use in solving problems

The ability of students in the second indicator, namely being able to analyze information displayed in various forms (graphs, tables, charts, diagram, and so on), is good but, there are still some students who have difficulty analyzing information, in other words, they do not understand the questions well This is in line with (Syafruddin et al., 2012) the difficulty of 
students in answering questions is due to the lack of understanding of students in mathematical problems, especially on story questions

Only a few students can meet the indicators, interpret the results of the analysis, which can be seen from the results of students' answers, there are only a few students who have good grades. The student's error in drawing this conclusion is because students are still wrong in the analysis of the problem so that in interpreting the results of the analysis it is still not accurate, one of the descriptors is to make conclusions, students make mistakes in concluding, also because of errors in calculations. Where this is in line with research (Ikhsana, 2020) which says that students tend not to be careful in calculations so that the conclusions obtained are not as desired.

The use of the context that is trending, in this case, the context of covid-19, namely the plan of the isolation room for covid-19 patients, from the results of the student interviews it was said that besides attracting students' attention because they were often discussed, it is also new information that students get after working on questions, information obtained from students where 3 out of 4 students just know the shape of the isolation room in the hospital, while one student already knows because the student has been isolated in the hospital. This research is also relevant to (Zulkardi et al., 2020) which used Covid-19 as context.

\section{CONCLUSION AND SUGGESTIONS}

Based on the results of research that has been conducted in grade VII of Harapan Mulia integrated Islamic Junior High School Palembang. The Numeration Ability of students in working on algebraic questions in the context of Covid-19 For indicators that most often appear are indicators using various kinds of numbers or symbols related to basic mathematics in solving daily life problems, then the indicators can analyze the information displayed in various forms (graphs, tables, charts, diagrams, and so on). The least frequently occurring indicators are interpreting the results of the analysis to predict and make decisions. Where students are accustomed to counting rather than analyzing and drawing conclusions. The use of contexts that are trending in society, in this case, Covid-19 is appropriate because it makes students more interested in working on questions and is interested in the new information they get. For further research, it can conduct more in-depth research on numeracy skills and use treatment in the form of learning models and approaches in seeing students' numeracy abilities.

\section{ACKNOWLEDGEMENT}

Authors would like to express gratitude to Elika Kurniadi, M.Sc., and Meryamsumayeka, M.Sc. as expert review and to Harapan Mulia integrated Islamic Junior High School Palembang, Ms. Jayanti Dwi Utari, S.Pd. and her students for participating in this research. Also to Duano Sapta Nusantara, S.Pd who contributed to the writing of this article. As well as those who have helped this research in developing and writing this article.

\section{REFERENCES}

Cai, J., Lew, H. C., Morries, A., Moyer, J. C., Ng, S. F., \& Schmittau, J. (2005). The Development of Students' Algebraic Thinking in Earlier Grades: A Cross-Cultural Comparative Perspective. ZDM International Journal on Mathematics Education, 37(1), 5-14. 
https://doi.org/10.1007/BF02655892

DeMatthews, D., Knight, D., Reyes, P., Benedict, A., \& Callahan, R. (2020). From the Field: Education Research During a Pandemic. Educational Researcher, 49(6), 398-402. https://doi.org/10.3102/0013189X20938761

Dewey, J. (2020). Konsep “ Merdeka Belajar " Perspektif Aliran Progresivisme. Jurnal Studi Guru Dan Pembelajaran, 3(1), 141-147.

GLN. (2017). Materi Pendukung Literasi Numerasi. In Kementerian Pendidikan Dan Kebudayaan (Vol. 8, Issue 9).

Güngör, A., Karaman, M. A., Sarı, H. İ., \& Çolak, T. S. (2020). Investigating the Factors Related to Coronavirus Disease 2019 (COVID-19) on Undergraduate Students' Interests in Coursework. International Journal of Psychology and Educational Studies, 7(3), 1-13. https://doi.org/10.17220/ijpes.2020.03.001

Handayu, A. R. (2020). Analisis Terhadap Butir Soal Asesmen Kompetensi Minimum (AKM) Tingkat SMP Ditinjau Dari Domain Lierasi Matematis PISA. 2018, 2018-2021.

Hott, B. L., \& Dibbs, R. A. (2020). A Qualitative Synthesis of Algebra Intervention Research. International Journal of Research in Education and Science (IJRES), 6(1), 34-47.

Ikhsana. (2020). Analisis Kemampuan Literasi Matematis Siswa SMP Kelas VIII pada Pembelajaran Berbasis Modelling Mathematics Berbantuan Media Virtual Menggunakan Geogebra Ditinjau dari Gaya Kognitif.

Jannah, R. D., Putri, R. I. I., \& Zulkardi. (2019). Soft tennis and volleyball contexts in asian games for pisa-like mathematics problems. Journal on Mathematics Education, 10(1), 157-169. https://doi.org/10.22342/jme.10.1.5248.157-170

Juniarti, Sukestiyarno, Y. L., Mulyono, \& Dwidayati, N. K. (2017). The Process of Structure Sense of Group Prerequisite Material: A Case in Indonesian Context. European Journal of Educational Research, 9(3), 1047-1061. https://doi.org/10.12973/eu-jer.9.3.1047

Jupri, A., Drijvers, P., \& van den Heuvel-Panhuizen, M. (2014). Difficulties in initial algebra learning in Indonesia. Mathematics Education Research Journal, 26(4), 683-710. https://doi.org/10.1007/s13394-013-0097-0

Koçoğlu, E., \& Tekdal, D. (2020). Analysis of distance education activities conducted during COVID-19 pandemic. Educational Research and Reviews, 15(9), 536-543. https://doi.org/10.5897/err2020.4033

Kus, M. (2018). Numeracy. Brock Education Journal, 27(2), 58-62.

Kusaeri. (2020). Reorientasi Penilaian Pembelajaran Matematika: Dulu, Kini, dan Mendatang. JDS Digital Printing.

Maharani, L., Indra Putri, R. I., \& Hartono, Y. (2019). Aquatic in Asian games: Context of pisa-like mathematics problem. Journal on Mathematics Education, 10(3), 459-470. https://doi.org/10.22342/jme.10.3.5252.459-470

Mahmud, M. R., \& Pratiwi, I. M. (2019). Literasi Numerasi Siswa Dalam Pemecahan Masalah Tidak Terstruktur. KALAMATIKA Jurnal Pendidikan Matematika, 4(1), 69-88. https://doi.org/10.22236/kalamatika.vol4no1.2019pp69-88

Maulidina, A. P. (2019). Profil Kemampuan Numerasi Siswa Sekolah Dasar Berkemampuan Tinggi Dalam Memecahkan Masalah Matematika. Jurnal Bidang Pendidikan Dasar, 3(2), 61-66. https://doi.org/10.21067/jbpd.v3i2.3408

Maulidina, A. P., \& Hartatik, S. (2019). Profil Kemampuan Numerasi Siswa Sekolah Dasar Berkemampuan Tinggi Dalam Memecahkan Masalah Matematika. Jurnal Bidang Pendidikan Dasar, 3(2), 61-66. https://doi.org/10.21067/jbpd.v3i2.3408

Mazana, Y. M., Montero, C. S., \& Casmir, R. O. (2019). Investigating Students' Attitude towards Learning Mathematics. International Electronic Journal of Mathematics Education, 14(1), 207-231. https://doi.org/https://doi.org/10.29333/iejme/3997

MOEC. (2016). Regulation of The Minister of Education and Culture Number 21 of 2016 concerning Content Standards for Primary and Secondary Education. Mendikbud. www.iranesrd.com

Moralista, R. B., \& Oducado, R. M. F. (2020). Faculty Perception toward Online Education in a State College in the Philippines during the Coronavirus Disease 19 (COVID-19) Pandemic. Universal 
Journal of Educational Research, 8(10), 4736-4742. https://doi.org/10.13189/ujer.2020.081044 Mustaghfiroh, S. (2020). Konsep "Merdeka Belajar” Perspektif Aliran Progresivisme John Dewey. Jurnal Studi Guru Dan Pembelajaran, 3(1 SE-Articles), 141-147. https://ejournal.my.id/jsgp/article/view/248

Muta'ali, J. A. (2020). Opini Masyarakat Tentang Asesmen Nasional Sebagai Penganti Ujian Nasional. Journal of Chemical Information and Modeling, 53(9), 1689-1699.

Nusantara, D. S., Zulkardi, \& Putri, R. I. I. (2020a). Designing PISA-like mathematics problem in covid19 pandemic (PISAComat). Journal of Physics: Conference Series, 1657(1). https://doi.org/10.1088/1742-6596/1657/1/012057

Nusantara, D. S., Zulkardi, Z., \& Putri, R. I. I. (2020b). Designing PISA-like mathematics problem relating change and relationship using physical distancing context. Journal of Physics: Conference Series, 1663(1). https://doi.org/10.1088/1742-6596/1663/1/012004

OECD. (2019). PISA 2018 Results. Combined Executive Summaries. Journal of Chemical Information and Modeling, 53(9), 1689-1699. www.oecd.org/about/publishing/corrigenda.htm.

Rawani, D., Putri, R. I. I., \& Hapizah. (2019). PISA-like mathematics problems: Using taekwondo context of Asian games. Journal on Mathematics Education, 10(2), 277-288. https://doi.org/10.22342/jme.10.2.5243.277-288

Sugiyono. (2017). Metode Penilitian Pendidikan Pendekatan Kuantitatif, Kualitatif, dan R\&D. ALFABETA. Syafruddin, S., Nurhayati, N., \& Wati, R. (2012). Pengaruh jenis pupuk terhadap pertumbuhan dan hasil beberapa varietas jagung manis. Jurnal Floratek, 107-114. http://www.jurnal.unsyiah.ac.id/floratek/article/view/524

Tohir, M. (2019). Merdeka Belajar. In Kementerian Pendidikan Dan Kebudayaan.

Wijaya, A. (2016). Aljabar: Tantangan Beserta Pembelajarannya. Jurnal Gantang, 1(1), 1-15. https://doi.org/10.31629/jg.v1i1.1

Yansen, D., Putri, R. I. I., Zulkardi, \& Fatimah, S. (2019). Developing pisa-like mathematics problems on uncertainty and data using asian games football context. Journal on Mathematics Education, 10(1), 37-46. https://doi.org/10.22342/jme.10.1.5249.37-46

Zulkardi, Meryansumayeka, Putri, R. I. I., Alwi, Z., Nusantara, D. S., Ambarita, S. M., Maharani, Y., \& Puspitasari, L. (2020). How students work with pisa-like mathematical tasks using covid-19 context. Journal on Mathematics Education, 11(3), 405-416. https://doi.org/10.22342/jme.11.3.12915.405-416 